\title{
Evaluation of the Trifluoromethanosulfonic Acid/Trifluoroacetic Acid/Thioanisole Cleavage Procedure for Application in Solid-Phase Peptide Synthesis ${ }^{1,2}$
}

\author{
Guita N. Jubilut, ${ }^{a}$ Eduardo M. Cilli, ${ }^{a}$ Mineko Tominaga, ${ }^{a}$ Antonio Miranda, ${ }^{a}$ Yoshio Okada,${ }^{b, c}$ and \\ Clovis Ryuichi NAKAIE ${ }^{*, a}$ \\ Department of Biophysics, Universidade Federal de São Paulo, ${ }^{a}$ Rua 3 de Maio 100, CEP 04044-020, SP, Brazil and \\ Faculty of Pharmaceutical Sciences ${ }^{b}$ and High Technology Research Center, ${ }^{c}$ Kobe Gakuin University, Nishi-ku, Kobe \\ 651-2180, Japan. Received March 5, 2001; accepted April 23, 2001
}

\begin{abstract}
As an extension of our investigation of peptidyl-resin linkage stability towards different cleavage procedures used in the solid-phase peptide synthesis (SPPS) technique, the present paper evaluated the trifluoromethanesulfonic acid (TFMSA)/trifluoroacetic acid (TFA)/thioanisole method, varying the type of resin (benzhydrylamineresin, BHAR; methylbenzhydrylamine-resin, MBHAR and 4-(oxymethyl)-phenylacetamidomethyl-resin, PAMR) and peptide resin-bound residue (Gly and Phe). The vasoactive angiotensin II (AII, DRVYIHPF) and its [Gly ${ }^{8}$ ]AII analogue linked to those resins used routinely in tert-butyloxycarbonyl (Boc)-SPPS chemistry were submitted comparatively to a time course study towards TFMSA/TFA cleavage. At $0^{\circ} \mathrm{C}$, $\left[\mathrm{Gly}^{8}\right]$-AII was completely removed from all resins in less than $6 \mathrm{~h}$, but the hydrophobic Phe $^{8}$ moiety-containing AII sequence was only partially cleaved (not more than $15 \%$ ) from BHAR or MBHAR in this period. At $25^{\circ} \mathrm{C}$, [Gly ${ }^{8}$ ]-AII cleavage time decreased to less than $2 \mathrm{~h}$ irrespective of the solid support, and quantitative removal of AII from PAMR and MBHAR occurred in less than $3 \mathrm{~h}$. However, about $10-15 \mathrm{~h}$ seemed to be necessary for cleavage of AII from BHAR, and in this extended cleavage reaction a significant increase in peptide degradation rate was observed. Regardless of the cleavage temperature used, the decreasing order of acid stability measured for resins was BHAR $>$ MBHAR $>$ PAMR. Collectively, these findings demonstrated the feasibility of applying TFMSA/TFA solution as a substitute for anhydrous HF at the cleavage step in Boc-SPPS methodology. Care should be taken however, as the cleavage efficacy depends on multiple factors including the resin, peptide sequence, the time and temperature of reaction.
\end{abstract}

Key words peptide synthesis; peptidyl-resin cleavage; trifluoromethanesulfonic acid; 4-(oxymethyl)-phenylacetamidomethylresin; benzhydrylamine-resin; methylbenzhydrylamine-resin

We recently reported ${ }^{3)}$ a rule for resin selection routinely used in tert-butyloxycarbonyl (Boc)-peptide synthesis chemistry. ${ }^{4,5)}$ This study was based upon the quantitative determination of the lability of model peptidyl-resin linkages towards both TFA amine group deprotection and HF final peptide cleavage steps. These effects depend basically upon the lability of the peptide-resin linkage which, in turn, is affected by the resin itself, the C-terminal amino acid and how often this chemical bond is submitted to TFA treatment (possibility of premature chain loss) during peptide growth. A rule for the choice of the best resin to be used depending on the peptide sequence to be synthesized was proposed. However, due to well-known practical and safety problems concerning use of the HF method, other acidolytic strategies have been proposed in the literature. ${ }^{6-8)}$ The present work alternatively evaluates the potentiality of the TFMSA/TFA/thioanisole cleavage method ${ }^{9-11)}$ for Boc-solid phase synthesis.

Thus, the present investigation reports data found in the time-course study of TFMSA/TFA/thioanisole treatment of peptidyl-resins using solid supports routinely applied for Boc-peptide synthesis chemistry. Amongst these, the benzhydrylamine-resin (BHAR) ${ }^{12)}$ and methylbenzhydrylamineresin (MBHAR) ${ }^{13)}$ are both used for the synthesis of peptideamides and 4-(oxymethyl)-phenylacetamidomethyl-resin $(\text { PAMR })^{14)}$ for peptide-acids. The vasoactive angiotensin II (AII, DRVYIHPF) ${ }^{15)}$ and its $\left[\mathrm{Gly}^{8}\right]$-AII analogue were selected. Although this cleavage procedure is used routinely at low temperature in solution synthesis, ${ }^{16,17)}$ we decided to compare the rate of peptide chain removal from a total of six peptidyl-resins at both $0{ }^{\circ} \mathrm{C}$ and $25^{\circ} \mathrm{C}$. Therefore, the main goal was to investigate the influence of different factors upon the efficacy of the TFMSA/TFA method. These findings would further facilitate the resin selection to be used and the correct protocol for application of the acid cleavage method which may depend on the type of peptide sequence to be assembled.

Table 1 shows the TFMSA/TFA/thioanisole comparative cleavage yields at $0^{\circ} \mathrm{C}$ of Phe or Gly-bearing AII at its C-terminal position and bound to BHAR, MBHAR and PAMR. As expected $\left[\mathrm{Gly}^{8}\right]$-AII was much more easily removed from the resin than the hydrophobic or larger Phe residue-containing AII sequence. If the lability dependence to the type of resin was considered, the following decreasing order of peptidyl-resin stability was observed: BHAR $>$ MBHAR $>$ PAMR. Intriguingly, the higher lability of peptide linkage to

Table 1. Percentage of TFMSA/TFA/Thioanisole Cleavage (at $0^{\circ} \mathrm{C}$ ) of $\mathrm{AA}^{8}$-AII-Resins

\begin{tabular}{lrrrrr}
\hline \hline \multirow{2}{*}{ Peptidyl-resin } & \multicolumn{5}{c}{ Cleavage time (h) } \\
\cline { 2 - 6 } & 0.5 & \multicolumn{1}{c}{1} & \multicolumn{1}{c}{2} & \multicolumn{1}{c}{4} & 6 \\
\hline$\left[\mathrm{Gly}^{8}\right]$ AII-BHAR & 15 & 39 & 62 & 83 & 100 \\
{$\left[\mathrm{Gly}^{8}\right]$ AII-MBHAR } & 37 & 64 & 100 & - & - \\
{$\left[\mathrm{Gly}^{8}\right]$ AII-PAMR } & 78 & 91 & 100 & - & - \\
{$\left[\mathrm{Phe}^{8}\right]$ AII-BHAR } & 0 & 0 & 0 & 1 & 5 \\
{$\left[\mathrm{Phe}^{8}\right]$ AII-MBHAR } & 0 & 1 & 6 & 12 & 13 \\
{$\left[\mathrm{Phe}^{8}\right]$ AII-PAMR } & 38 & 82 & 100 & - & - \\
\hline
\end{tabular}

(C) 2001 Pharmaceutical Society of Japan 
PAMR than to MBAR is not in agreement with previous results obtained during peptidyl-resin $\mathrm{HCl}$ /propionic acid hydrolysis $^{18)}$ or time course HF and TFA ${ }^{3)}$ investigations.

The $\left[\mathrm{Gly}^{8}\right]$-AII sequence was completely removed in approximately $2 \mathrm{~h}$ from PAMR and MBHAR and in $6 \mathrm{~h}$ from BHAR at $0{ }^{\circ} \mathrm{C}$, while the more stable $\left[\mathrm{Phe}^{8}\right]$-AII-resin linkage was cleaved quantitatively in $2 \mathrm{~h}$ from PAMR but only partially from MBHAR or BHAR. At this low temperature, the yield of $\left[\mathrm{Phe}^{8}\right]$-AII cleavage bound to these two amineresins reached values as low as 13 and 5\%, respectively, after extended $6 \mathrm{~h}$ reaction. By comparing results earlier reported for these two peptidyl-resins at $0{ }^{\circ} \mathrm{C}$ in $\mathrm{HF}^{3)}$ the apparent rate of cleavage seems to be higher in this than in the TFMSA/ TFA-containing mixed solution.

In an advantage over the HF method where use of a low temperature is mandatory, ${ }^{19)}$ the TFMSA/TFA strategy might allow an increase in temperature during the cleavage process. Table 2 displays the time course data obtained at $25^{\circ} \mathrm{C}$. As expected, $\left[\mathrm{Gly}^{8}\right]$-AII removal from MBHAR and BHAR was accelerated (around 2 and $3 \mathrm{~h}$, respectively) but for the more acid stable $\left[\mathrm{Phe}^{8}\right]$-AII-resin linkage, the peptide sequence was only quantitatively cleaved after approximately $3 \mathrm{~h}$ and $10-20 \mathrm{~h}$ when bound to MBHAR and BHAR, respectively.

At this latter forceful cleavage condition, a decrease in the peptide purity was monitored through analytical RP-HPLC. Figure 1 shows the corresponding chromatogram profiles of crude AII cleaved from BHAR in 1,6 and $24 \mathrm{~h}$ with

Table 2. Percentage of TFMSA/TFA/Thioanisole Cleavage of AA $^{8}$-AIIResins at $25^{\circ} \mathrm{C}$

\begin{tabular}{lrrrrrrr}
\hline \hline \multirow{7}{*}{ Peptidyl-resin } & \multicolumn{7}{c}{ Cleavage time (h) } \\
\cline { 2 - 8 } & 0.5 & 1 & 2 & 3 & 4 & 6 & 24 \\
\hline$\left[\mathrm{Gly}^{8}\right]$ AII-BHAR & 75 & 88 & 97 & 100 & - & - & - \\
{$\left[\mathrm{Gly}^{8}\right]$ AII-MBHAR } & 87 & 96 & 100 & - & - & - & - \\
{$\left[\mathrm{Phe}^{8}\right]$ AII-BHAR } & - & 20 & 70 & 73 & 84 & 87 & 100 \\
{$\left[\right.$ Phe $\left.^{8}\right]$ AII-MBHAR } & - & 49 & 89 & 100 & - & - & - \\
\hline
\end{tabular}

TFMSA/TFA at $25^{\circ} \mathrm{C}$. After a cleavage time of nearly $6 \mathrm{~h}$, it is possible to see the appearance of a contaminant overlapped with the AII main peak (at around $6 \mathrm{~min}$ ) which increased significantly in the 24 h-cleavage time HPLC profile. By quantifying the main peak area in each displayed chromatogram, it is possible to conclude that peptide degradation yield reached values around $20-25 \%$ in $24 \mathrm{~h}$. Certainly this degradation rate might be more related to AII-type sequence. Further experimental investigations are needed with other sequences to better evaluate the validity in associating high temperature with extended cleavage reaction time.

Lastly, to better evaluate the rule for TFMSA/TFA application depending upon the resin, peptide length and the nature of its C-terminal residue, Table 3 presents the theoretical syntheses yield estimated when, for instance, cleavage of a short and long (16 and 40-mer) peptide sequence is to be carried out at $0{ }^{\circ} \mathrm{C}$ and $25^{\circ} \mathrm{C}$. For this estimation, the most common $2 \mathrm{~h}$-cleavage time was employed for quantitative estimation of the overall decrease in synthesis yield. These values were obtained by considering simultaneously the already quantified yield of chain loss of these peptides during 8 and $20 \mathrm{~h}-\mathrm{TFA}$ deprotection ${ }^{3}$ (corresponding to $30 \mathrm{~min}$ treatment of both 16 and 40 amino acid-long peptides) and the incomplete TFMSA/TFA cleavage values displayed in Tables 1 and 2. This was done simply by multiplying the yield of both acid treatments, in percentage. It must be stressed that no other source of side reactions or chemical problems during the synthesis was considered, other than that derived from the TFA and final cleavage steps.

The analysis of data displayed in Table 3, in association with those of Tables 1 and 2 provided the following conclusions/comments:

(i) Despite the resin or peptide sequence, PAMR is always adequate for TFMSA/TFA cleavage regardless of temperature. The lowest yield when using this resin (88\%, Table 3) can be estimated, when a 40-mer long sequence is going to be synthesized. The $12 \%$ decrease in the yield is essentially due to the chain loss during the prolonged $(20 \mathrm{~h})$ TFA treat-
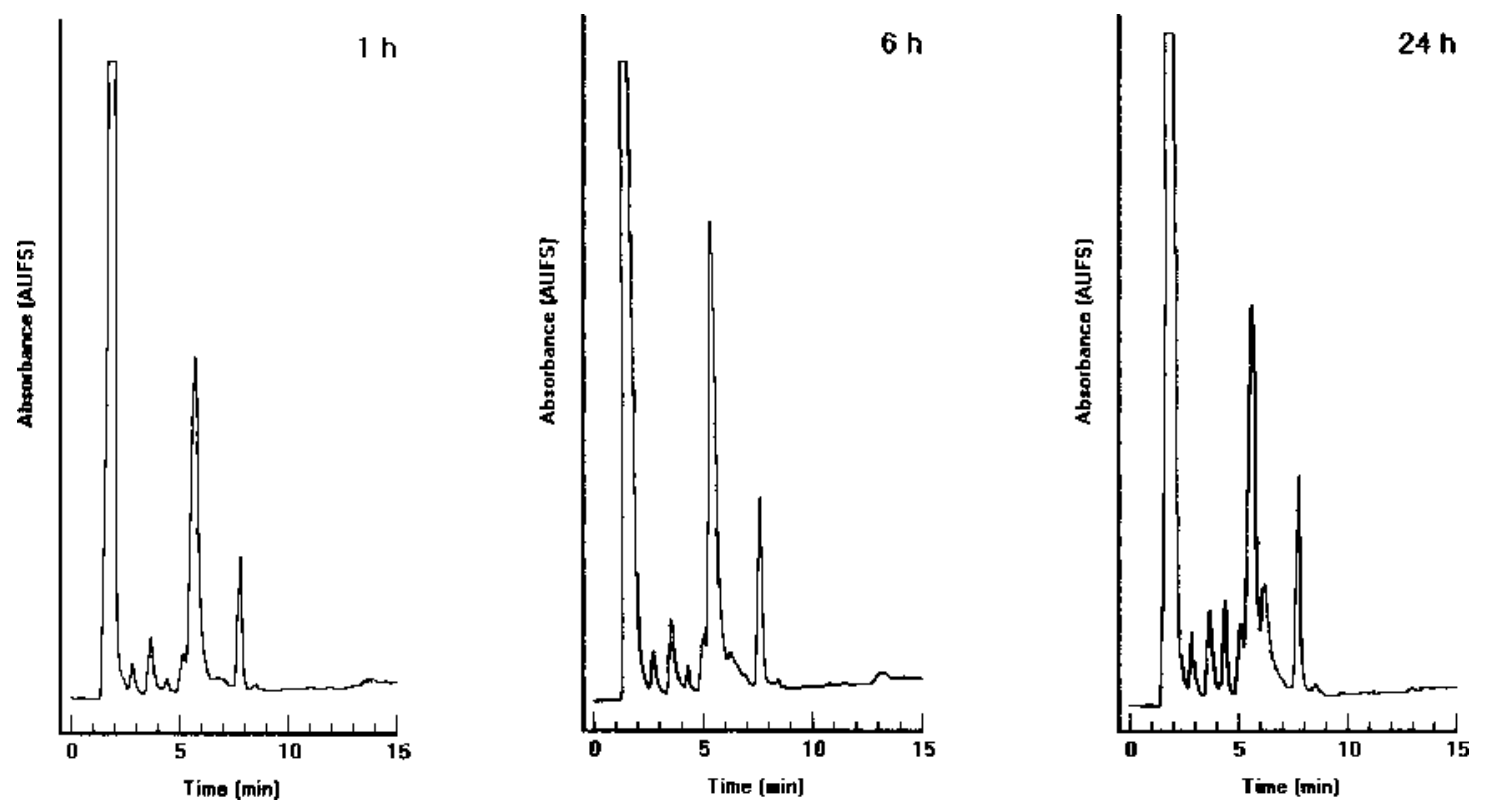

Fig. 1. RP-HPLC Profiles of the $\left[\mathrm{Phe}^{8}\right]$-AII-BHAR after 1,6 and $24 \mathrm{~h}$ TFMSA/TFA/Thioanisole Treatment at $25^{\circ} \mathrm{C}$ 
Table 3. Theoretical Synthesis Yield of Model Peptidyl-Resins Considering the TFA and $2 \mathrm{~h}$ TFMSA/TFA/Thioanisole Treatments at $0{ }^{\circ} \mathrm{C}$ and $25^{\circ} \mathrm{C}^{a)}$

\begin{tabular}{|c|c|c|c|c|c|c|}
\hline \multirow{3}{*}{$\begin{array}{c}\text { Resins } \\
\text { Number of residues }\end{array}$} & \multicolumn{6}{|c|}{ Theoretical yield (\%) } \\
\hline & \multicolumn{2}{|c|}{ BHAR } & \multicolumn{2}{|c|}{ MBHAR } & \multicolumn{2}{|c|}{ PAMR } \\
\hline & 16 & 40 & 16 & 40 & 16 & 40 \\
\hline C-terminal residue & \multicolumn{6}{|c|}{$0^{\circ} \mathrm{C}$} \\
\hline Gly & 60 & 57 & 96 & 86 & 96 & 88 \\
\hline \multirow[t]{2}{*}{ Phe } & 0 & 0 & 6 & 5 & 96 & 91 \\
\hline & \multicolumn{6}{|c|}{$25^{\circ} \mathrm{C}$} \\
\hline Gly & 94 & 89 & 96 & 86 & 96 & 88 \\
\hline Phe & 68 & 67 & 86 & 81 & 96 & 91 \\
\hline
\end{tabular}

a) No other sources of error or side reactions were considered in this study other than those derived from partial TFMSA/TFA/thioanisole or TFA peptide chain cleavages.

ment. No decrease in the yield is due to the cleavage step as it is complete in the 2 h-reaction.

(ii) Regarding MBHAR solid support, the feasibility of the use of TFMSA/TFA cleavage procedure is highly dependent on the nature of the C-terminal residue. For a hydrophilic and small amino acid such as Gly, it is possible to obtain over $85 \%$ synthesis yield, regardless of the temperature used in the reaction. However, its use is limited in the case of peptides with hydrophobic C-terminal residues such as Phe. Synthesis yield of about $80 \%$ (even at $25^{\circ} \mathrm{C}$ ) and not higher than $6 \%\left(\right.$ at $\left.0{ }^{\circ} \mathrm{C}\right)$ are expected when cleaving Phe-MBHARtype compound for $2 \mathrm{~h}$.

(iii) As expected, more severe restriction for use of the TFMSA/TFA method is observed when BHAR is employed. Acceptable yield is only obtained at higher temperature $\left(25^{\circ} \mathrm{C}\right)$ and when the peptide contains Gly-type hydrophilic residues at its carboxy-terminal portion. For sequences containing hydrophobic moiety at this position, the synthesis yield using BHAR does not reach $70 \%$ even at $25^{\circ} \mathrm{C}$, in the standardized $2 \mathrm{~h}$ cleavage protocol. This finding is relevant as we have already demonstrated that depending upon the peptide length and the nature of its $\mathrm{C}$-terminal residue, BHAR is more appropriate than MBHAR for peptide synthesis. ${ }^{3)}$ This is basically due to higher acid stability of peptide-BHAR linkage which avoids premature peptide chain detachment from the resin during the prolonged TFA treatment.

(iv) To protect the peptide integrity when solution synthesis is used, most chemists carry out TFMSA/TFA cleavage at $0{ }^{\circ} \mathrm{C}$. Our results emphasized that neither MBHAR nor BHAR can be employed at this low-temperature condition when attaching peptides containing hydrophobic residue at their C-terminal position. In this case, syntheses yields around $6 \%$ and zero are estimated for these two resins, respectively. In the more severe case (BHAR), even if a peptide sequence containing hydrophilic moiety at its C-terminal portion is synthesized, the final yield did not achieve values higher than $60 \%$ (Table 3 ).

In conclusion, the feasibility of using the TFMSA/TFA/ thioanisole cleavage procedure for Boc-SPPS was demonstrated but with some restrictions. Higher cleavage temperature combined with extended reaction time might be a valid alternative to overcome some of these problems. Care should be taken in this case, mainly concerning possible degradation of the peptide sequence containing acid-labile residues. Despite this shortcoming the most relevant advantage of the TFMSA/TFA method lies in its simplicity and safety compared with the HF procedure which requires a special perflon-type apparatus and the handling of a very dangerous vapor acid.

Since its inception, the SPPS methodology has been progressively improved through a great variety of experimental investigations aiming for instance, to overcome incomplete $\alpha$-amine group deprotection, ${ }^{20)}$ difficulties in coupling reactions with the use of efficient acylating reagent, ${ }^{21,22)}$ elevated temperature $^{23,24)}$ or by enhancing the knowledge of the peptidyl-resin solvation phenomenon. ${ }^{25,26)}$ Spectroscopic techniques of $\mathrm{NMR},{ }^{27,28)} \mathrm{IR}^{29,30)}$ or $\mathrm{EPR}^{31,32)}$ with the use of a paramagnetic amino acid $^{33)}$ or associated with fluorescence ${ }^{34)}$ have been intensively applied to achieve the same objective. In this context, the decrease in overall synthesis yield due to premature chain detachment in the TFA step combined with possible incomplete peptide cleavage from the resin has been routinely neglected. The present work emphasized that depending upon the chemical strategy to be used, this decrease in synthesis yield as a consequence of these two acid steps of the synthesis cycle can be comparatively relevant.

\section{Experimental}

Most of the solvents and reagents were purchased from Fluka or Aldrich and all met ACS standards. Trifluoroacetic acid was acquired from Fluka and the anhydrous hydrogen fluoride (51 capacity cylinder) was from Merck Co.

Peptide Synthesis Stepwise build-up of the peptides was done manually by Boc-chemistry solid phase methodology. Benzhydrylamine resin (BHAR), methylbenzhydrylamine resin (MBHAR) and 4-(oxymethyl)phenylacetamidomethyl-linker-containing resins (PAMR) with substitution degree ranging from 0.2 to $0.6 \mathrm{mmol} / \mathrm{g}$ were used. These resins were acquired from different companies (Advanced Chemtech, Novabiochem, Peninsula and Bachem). The $N^{\alpha}$-tert-butyloxycarbonyl (Boc) protecting group was removed with $30 \%$ trifluoroacetic acid (TFA) in dichloromethane (DCM) in the presence of $2 \%$ anisole for $30 \mathrm{~min}$. The following side chain protecting groups were used: mesitylene-2-sulfonyl (Mts) for Arg and benzyloxymethyl (Bom) for His, 2-bromobenzyloxycarbonyl (2-BrZ) for Tyr and cyclohexyl group (cHex) for Asp. Amine group neutralization was performed for $1 \times 1 \mathrm{~min}$ and $1 \times 10 \mathrm{~min}$ with $10 \%$ triethylamine (TEA). Coupling reactions were done using 2.5 excess of Boc-amino acid/2-( $1 H$-benzotriazol-1-yl)-1,1,3,3-tetramethyluronium tetrafluoroborate (TBTU)/diisopropylethylamine (DIEA) $(1: 1: 2)$ in DCM or in $1: 1(\mathrm{v} / \mathrm{v}) \mathrm{DCM} /$ dimethylformamide (DMF) mixture. All couplings were monitored by qualitative ninhydrin test. Before TFMSA and TFA time-course investigations, a small amount of each sample was cleaved by HF. The purity of the crude peptide was assessed by analytical reverse-phase high performance liquid chromatography (RP-HPLC) and the structure was confirmed by the LC/MS and amino acid analysis.

Amino Acid Analysis Prior to the TFMSA and TFA time-course studies, all peptidyl-resins were hydrolyzed with $12 \mathrm{~N} \mathrm{HCl}$ /propionic acid mixture for $100 \mathrm{~h}$ at $130^{\circ} \mathrm{C}$ to guarantee quantitative removal of peptide chains from the resin as recently proposed. ${ }^{18)}$ Pyrex tubes with plastic Teflon-coated screw caps $(13 \times 1 \mathrm{~cm})$ were used for the hydrolyses and the amino acid analyses were performed in a Beckman System 6300 amino acid analyzer to determine the amount of peptide attached to the resin.

TFMSA/TFA/Thioanisole Time Course Cleavage Study In several small round-bottom flasks equipped with a micro stirring bar, $50 \mu \mathrm{l}$ of $\mathrm{m}$ cresol and $124 \mu \mathrm{l}$ of thioanisole were added to isolated portions of protected peptide-resins (approximately $50 \mathrm{mg}$ each). After stirring for approximately $2 \mathrm{~min}, 736 \mu \mathrm{l}$ of TFA and $90 \mu \mathrm{l}$ of TFMSA were added to each flask at $0^{\circ} \mathrm{C}$ or $25^{\circ} \mathrm{C}$. Each resin underwent for cleavage reaction for different periods of time and was submitted to exhaustive washings with TFA/DCM, DCM, ethyl acetate, $\mathrm{DMF}$, water, $10 \% \mathrm{AcOH} /$ water and $\mathrm{MeOH}$ to guarantee the removal of all cleaved peptides and other side products of the reaction. After this treatment, small aliquots of each dried resin were hydrolyzed according to 
the previous report ${ }^{18)}$ for further amino acid analysis. The calculated peptide content of the cleaved resin was compared to the value of the initial peptidyl-resin, taken as $100 \%$. Otherwise when the purity of removed peptide was to be evaluated, the cleaved peptide was isolated by precipitation with cold ethyl ether in the resin, further extracted with $10 \% \mathrm{AcOH} /$ water and lyophilized.

Analytical RP-HPLC RP-HPLC analyses were achieved in TFA/acetonitrile gradient using a Waters Associates HPLC system consisting of two 510 HPLC pumps, automated gradient controller, Rheodyne manual injector, $486 \mathrm{UV}$ detector and 746 data module. Solvent A: $0.1 \% \mathrm{TFA} / \mathrm{H}_{2} \mathrm{O}$ and Solvent B: $60 \%$ acetonitrile $/ 0.1 \% \mathrm{TFA} / \mathrm{H}_{2} \mathrm{O}$ with a gradient of $5-95 \%$ of B in $30 \mathrm{~min}$, at a flow rate of $1.5 \mathrm{ml} / \mathrm{min}$ were used. The column employed was a Vydac $\mathrm{C}_{18}$ column $(0.46 \times 25 \mathrm{~cm}, 5 \mu \mathrm{m}$ particle size, $300 \AA$ pore size $)$, and detection at $\lambda=210 \mathrm{~nm}$.

Liquid Chromatography/Mass Spectrometry The crude lyophilized peptides were analyzed on a system composed of a Micromass Platform LCZ Spectrometer, a Waters Alliance HPLC, a Waters 996 photodiode array detector, and a Compaq Workstation. The peptides were loaded on a reversed-phase HPLC column Waters Nova-Pak $\mathrm{C}_{18}(2.1 \times 150 \mathrm{~mm}-3.5 \mu \mathrm{m}$ particle size, and $60 \AA$ pore size), Solvent $\mathrm{A}, 0.1 \% \mathrm{TFA} / \mathrm{H}_{2} \mathrm{O}$, and $\mathrm{B}, 0.1 \%$ TFA in $\mathrm{CH}_{3} \mathrm{CN} / \mathrm{H}_{2} \mathrm{O}$ at a flow rate of $0.4 \mathrm{ml} / \mathrm{min}$, detection at $210 \mathrm{~nm}$ in a mass range of $500-3930$ daltons.

Acknowledgments We thank CNPq, FAPESP and FINEP for financial support. CNPq research fellowships for A.M. and C.R.N. are also acknowledged.

\section{References and Notes}

1) Preliminary aspects of the present investigation were recently presented at the 26th European Peptide Symposium, in Montpellier, France (September 2000).

2) Abbreviations used in this report for amino acids, peptides and their derivatives are those recommended by the IUPAC-IUB Commission on Biochemical Nomenclature: Biochemistry, 5, 2485-2489 (1966); 6, 362-369 (1967); 11, 1726-1732 (1972). The symbols represent the L-isomer unless otherwise specified. The following additional abbreviations are used: $\mathrm{AcOH}$, acetic acid; 2- $\mathrm{Br}-\mathrm{Z}$, 2-bromobenzyloxycarbonyl; BHAR, benzhydrylamine-resin; Bom, benzyloxymethyl; Boc, tert-butyloxycarbonyl; Mts, mesitylene-2-sulfonyl for Arg, CMR, chloromethyl-resin; cHex, cyclohexyl; $\mathrm{C}_{18}$, octadecyl; DCM, dichloromethane; DIEA, diisopropylethylamine; DMF, dimethylformamide; $\mathrm{EPR}$, electron paramagnetic resonance; $\mathrm{HOBt}$, hydroxybenzotriazole; IR, infra-red; LC/MS, liquid chromatography/mass spectrometry; MBHAR, 4-methylbenzhydrylamine-resin; NMR, nuclear magnetic resonance; PAMR, 4-(oxymethyl)-phenylacetamidomethyl-linker-containing resin; RP-HPLC, reversed phase high performance liquid chromatography; TBTU, 2-(1H-benzotriazole-1-yl)-1,1,3,3-tetramethyluronium tetrafluoroborate; TEA, triethylamine; TFA, trifluoroacetic acid; Tos, $p$-toluenesulfonyl.

3) Jubilut G. N., Miranda M. T. M., Tominaga M., Okada Y., Miranda A., Nakaie C. R., Chem. Pharm. Bull., 47, 1560-1563 (1999).

4) Barany G., Merrifield R. B., "The Peptides," Vol. 2., ed. by Gross E., Meinhofer J., Academic Press, N.Y., 1980.

5) Stewart J. M., Young J., "Solid Phase Peptide Synthesis," Pierce Chemical Co., Rockford, IL., 1984.
6) Yajima H., Fujii N., Funakoshi S., Watanabe T., Murayama E., Otaka A., Tetrahedron, 44, 805-819 (1988).

7) Hughes J. L., Leopold E. J., Tetrahedron Lett., 34, 7713-7716 (1993).

8) Sparrow J. T., Monera O., Peptide Res., 9, 218-222 (1996).

9) Yajima H., Fujii N., Ogawa H., Kawatani H., Chem. Commun., 1974, $107-108$.

10) Yajima H., Fujii N., "The Peptides,” Vol. 5, ed. by Gross E., Meinhofer J., Academic Press, N.Y., 1983.

11) Kiso Y., Nakamura S., Ito K., Ukawa K., Kitagawa K., Akita T., Moritoki H., J. Chem. Soc. Chem. Commun., 1979, 971—972.

12) Pietta P. G., Cavallo P. F., Takahashi K., Marshall G. R., J. Org. Chem., 39, $44-48$ (1974).

13) Matsueda G. R., Stewart J. M., Peptides, 2, 45-50 (1981).

14) Mitchell A. R., Erickson B. W., Ryabtsev M. N., Hodges R. S., Merrifield R. B., J. Am. Chem. Soc., 98, 7357-7362 (1976).

15) Timmermans P. B. M. W. M., Carini D. J., Chiu A. T., Duncia J. V., Price W. A., Wells G. J., Wong P. C., Wexler R. R., Johnson A. L., Hypertension, 18, 136-142 (1991).

16) Akaji K., Fujii N., Yajima H., Hayashi K., Mizuta K., Aono M., Moriga M., Chem. Pharm. Bull., 33, 184-201 (1985).

17) Fujii N., Sakurai M., Akaji K., Nomizu M., Yajima H., Mizuta K., Aono M., Moriga M., Inoue K., Hosotani R., Tobe T., Chem. Pharm. Bull., 34, 2397-2410 (1986).

18) Jubilut G. N., Marchetto R., Cilli E. M., Oliveira E., Miranda A., Tominaga M., Nakaie C. R., J. Braz. Chem. Soc., 8, 65-70 (1997).

19) Sakakibara S., Chemistry and Biochemistry of Amino Acid Peptides and Proteins, 1, 51-85 (1971).

20) Bedford J., Hyde C., Johnson T., Wen J. J., Owen D., Quibell M., Sheppard R. C., Int. J. Peptide Protein Res., 40, 300-307 (1992).

21) Carpino L. A., El-Faham A., Minor C. A., Albericio F., J. Chem. Soc. Chem. Commun., 1994, 369-372.

22) Alberício F., Carpino L. A., Methods Enzymol., 289, 104-126 (1997).

23) Tam J. P., Int. J. Peptide Protein Res., 29, 421-431 (1987).

24) Varanda L. M., Miranda M. T. M., J. Peptide Res., 50, 102-108 (1997).

25) Fields G. B., Fields C. G., J. Am. Chem. Soc., 113, 4202-4207 (1991).

26) Cilli E. M., Oliveira E., Marchetto R., Nakaie C. R., J. Org. Chem., 81, 8992-9000 (1996).

27) Dhalluin C., Boutillon C., Tartar A., Lippens G., J. Am. Chem. Soc., 119, 10494-10500 (1997).

28) Ludwick A. G., Jelinski L. W., Live D., Kintamar A., Dumais J. J., J. Am. Chem. Soc., 108, 6493-6496 (1986).

29) Narita M., Honda S., Umeyama H., Ogura T., Bull. Chem. Soc. Jpn., 59, 2439-2443 (1988).

30) Henkel B., Bayer E., J. Pept. Sci., 63, 461-470 (1998).

31) Cilli E., Marchetto R., Schreier S., Nakaie C. R., Tetrahedron Lett., 38, 517-520 (1997).

32) Cilli E., Marchetto R., Schreier S., Nakaie C. R., J. Org. Chem., 64, 9118-9123 (1999).

33) Marchetto R., Schreier S., Nakaie C. R., J. Am. Chem. Soc., 115, 11042-11043 (1993)

34) Vaino A. R., Goodin D. B., Janda K. D., J. Comb. Chem., 2, 330-336 (2000). 